\title{
Forest Biomass Availability Analysis and Large-Scale Supply Options
}

\author{
Tapio Ranta, Olli-Jussi Korpinen, Eero Jäppinen, Kalle Karttunen \\ The Faculty of Technology, Lappeenranta University of Technology, Mikkeli, Finland \\ Email: tapio.ranta@lut.fi
}

Received September $27^{\text {th }}, 2011$; revised October $31^{\text {st }}, 2011$; accepted November $8^{\text {th }}, 2011$

\begin{abstract}
Finnish forest companies aim to produce biodiesel based on the Fischer-Tropsch process from forest residues. This study presents method to evaluate biomass availability and supply costs to the selected biorefinery site. Forest-owners' willingness to sell, buyers' market share, and regional competition were taken into account when biomass availability was evaluated. Supply logistics was based either on direct truck transportation deliveries from forest or on railway/waterway transportation via regional terminals. The large biomass need of a biorefinery demanded both of these supply structures, since the procurement area was larger than the traditional supply area used for CHP plants in Finland. The average supply cost was 17 $€ / \mathrm{MWh}$ for an annual supply of $2 \mathrm{TWh}$ of forest biomass. Truck transportation of chips made from logging residues covered $70 \%$ of the total volume, since direct forest chip deliveries from forest were the most competitive supply solution in terms of direct supply costs. The better supply security and lower vehicle capacity needs are issues that would favour also terminal logistics with other raw-material sources in practical operations. One finding was that the larger the biomass need, the less the variation in biomass availability and supply costs, since almost the whole country will serve as a potential supply area. Biomass import possibilities were not considered in this study.
\end{abstract}

Keywords: Logistics; Forest Residues; Supply Chain; Biorefinery

\section{Introduction}

In Finland, the target for renewable energy as a share of final energy consumption will be $38 \%$ by 2020 (Long-Term Climate and Energy Strategy, 2008). In the year of comparison 2005, the share was $28.5 \%$, but it has fallen to $26 \%$ in 2010 because of the declining production volumes in the forest industry (Statistics Finland, 2011). In particular, wood fuels will be tasked with a considerable share of the work to meet Finnish targets. Wood fuels accounted for $81 \%$ (308 PJ) of renewable energy primary use (380 PJ) in 2010 (Statistics Finland, 2011). The Climate and Energy Strategy of Finland presupposes wood fuel primary use to achieve the level of 335 PJ (forest chips: 76 PJ) under the base scenario or 349 PJ (forest chips: $86 \mathrm{PJ}$ ) in the target scenario by 2020 (Long-Term Climate and Energy Strategy, 2008). The target scenario strives toward the aim of RES for Finland. The difference between the scenarios follows from the increased forest chip use, while use of forest industry volume-dependent wood by-products and black liquor is forecast to decline according to both scenarios, which underpins the development of forest chip use. The study by Pöyry Energy (2009) estimated that supply by products would decline some 16\% (16 PJ) between 2005 and 2010.

Under the Climate and Energy Strategy, the total use of forest chips (86 PJ) involves some 12 million solid cubic metres. The latest aim stated by the Government of Finland is to increase this volume to the level of 13.5 million solid cubic metres (90 PJ). Techno-economical potential will lie somewhere around 151 168 PJ by 2020 (Pöyry Energy, 2009); therefore, the target is challenging to utlilise more than half of the potential within this time frame. Uncertainties arise from the development of roundwood felling levels, energy wood subsidy schemes, pricing of emission allowances and prices of alternative fuels. In addition, Finland aims to build three biorefineries, each needing at least 1 million $\cdot$ solid $\cdot \mathrm{m}^{3}$ of forest chips a year outside of the forest industry site. These targets and related incentives were announced in a national action plan sent for the European Commission in June 2010. The incentives included an energy subsidy for energy wood from first thinnings, a feed-in tariff for small-scale CHP ( $<20 \mathrm{MW})$ using forest chips, and a production subsidy dependent on EU-ETS allowance price for electricity produced from forest chips in co-combustion boilers $(>20 \mathrm{MW})$. The idea is to replace peat and coal with wood and link the level of the subsidy to the price development of $\mathrm{CO}_{2}$ allowances.

The development of forest chips' use has been rapid so far in the 21 century. From 2000 to 2010, the use of forest chips increased from $7 \mathrm{PJ}\left(0.9\right.$ million $\cdot$ solid $\left.\cdot \mathrm{m}^{3}\right)$ to $50 \mathrm{PJ}\left(6.9 \mathrm{million} \cdot \mathrm{solid} \cdot \mathrm{m}^{3}\right)$. The energy industry (district heat and power production) used 45 PJ and small houses 5 PJ in 2010 (Ylitalo, 2011). Forest chips consisted of logging residues $(36 \%)$, small-diameter energy wood (41\%), stumps (16\%), and roundwood (8\%).

So far, all forest chips (both uncomminuted and comminuted material) have been transported by truck, except in trials with railway and waterway vehicles in the inland lake area. It was found that waterway transportation may become an option with longer transport distances (over $150 \mathrm{~km}$ ) if the barge logistics is managed well and barge structures modified for forest chip transportation (Karttunen et al., 2008). A winter season with iced-over lake areas (3 - 4 months) will decrease the logistical effectiveness of the waterway system. In contrast, railway logistics offers more route options and year-round operation possibilities. Experiences of railway logistics for forest chips from Sweden have been promising (Enström, 2008). The terminal operations are 
an especially essential part of railway logistics for keeping the train capacity in use (Korpinen et al., 2008).

It could be expected that other transport modes will claim a certain part of domestic transport markets for forest chips. Larger forest chip supply volumes calls for logistics systems including buffer terminals and transport modes suitable for longer distances. Supply costs will increase because of more handling and storage, but at the same time it is possible to increase the availability and supply security.

The larger forest chip volumes and longer transport distances will be clearly manifested with biorefineries despite their integration into paper and pulp mills. Finnish forest companies aim to produce biodiesel from domestic forest chip raw-material sources, where the biofuel production technology will use the Fischer-Tropsch process. At the moment, the production technology is being further developed and evaluated for forest chips through demonstration and pilot plants. Also tentative production sites for commercial-scale plants have been selected and biomass availability estimated. In practical terms, only existing forest integrates would be suitable sites in Finland. The advantages of process integration will increase the conversion efficiency from $60 \%$ to $90 \%$ (McKeough \& Kurkela, 2008). There are three groups of operators interested in investing in a biorefinery and thus three parallel projects in progress in Finland. The additional biomass need per commercial site is at least 1 million $\cdot \mathrm{m}^{3}$, i.e., $2 \mathrm{TWh}$ of biomass and hundreds of truckloads per day, depending on the use of other modes of transport. The maximum need would be double this: 4 TWh of biomass.

The analysis tool reported upon in this study will be targeted at assisting availability and alternative supply chain studies for potential biorefinery sites in Finland. The biorefinery scale is commercial, with production of 100,000 tonnes of biodiesel a year. The analysis will be bound to a regional operational environment of supply infrastructure, including alternative transport networks such as roads, inland waterways and railways, potential forest biomass resources and alternative supply logistics structures. Regional competition is an important part of the study, for evaluating realistic biomass availability. Logistical structures dictate how the supply chain is constructed between supply and demand site including storage phases and the form in which material is handled in the various stages. Geographical information system (GIS) use is applied for analysing biomass resources in a competitive situation among end users and alternative supply logistics structures and for examining supply costs.

\section{Material and Methods}

\section{Forest Biomass Reserves}

Calculations of biomass potential were based on commercial fellings reported upon at municipality level in Metinfo forest information services in 2009. Volumes were obtained for 20042008 and averaged. The biomass calculation method was reported upon in an earlier study, where techno-economical logging residue and stump volumes were converted from roundwood felling volumes (Laitila et al., 2008). The calculation method for small-diameter energy wood was based on National Forest Inventory data and also reported in the earlier study (Anttila et al., 2009). Biomass volumes at municipal level (448 units) were distributed over smaller collection points (55,292 units). These points were based on actual regeneration felling points from 2002 to 2004. In this way, the municipal volume was spread to forestry land where fellings will occur also in the future. The volume was divided equally across points within each municipality, for more fine-grained geographical coverage. The coverage of collection points was greater in areas where regeneration felling activity has been higher, such as eastern and central Finland (see Figure 1). With the volume assigned to these points, the regional availability and logistics calculations could be made more detailed.

\section{Competition among End Users}

Alternative end users of forest chips were geographically pinpointed to take into account the regional competition. Only large-scale users with more than $50 \mathrm{GWh}$ of annual actual or planned use (approx. 30 sites) were selected (Figure 1). In practice, these were municipal or industrial CHP plants. Also future potential user sites were taken into account, where the investment has been decided on or is under construction. No potential biorefinery sites were selected, as no construction site decision has yet been made. Small-scale heating plant sites (approx. 400) were omitted, since their effect on regional use is rather low. Large-scale users account for $75 \%$ of forest chips' end use, and the small-scale use could have been incorporated into large-scale use (Ylitalo, 2011). The regional coverage of users was extensive except in northern Finland.

The forest chips are supplied mainly in the proximity of existing CHP plants, since the typical procurement area lies within $100 \mathrm{~km}$. Because of the extensive geographical coverage and plants' proximity to each other, the procurement areas are overlapped, especially in the southern part of Finland. End users have access to only certain of the biomass sources surrounding the plants, since the biomass supply market is oligopolistic by nature. Many organisations supply biomass to alternative end users in the same region; in this study, the maximum market share was assumed to be $50 \%$.

At first, for each CHP plant the supply areas were calculated via road network to build an isodistance area (same road distance at outer ring) that could meet the full demand. This area was called the inside supply area. From this area, 50\% was allocated to the plant accounting for the maximum market share.

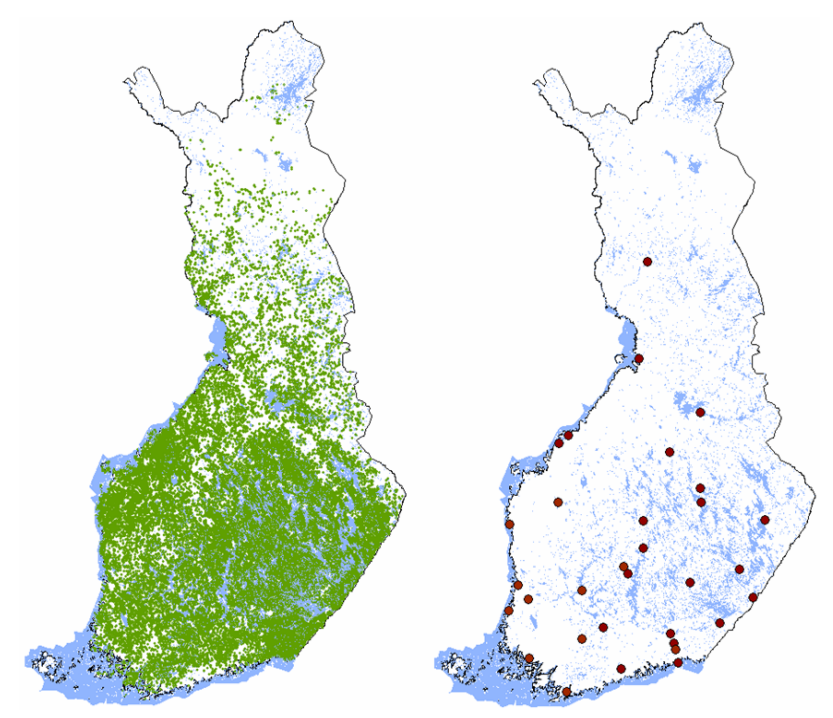

Figure 1.

The coverage of forest biomass collection points at the left side map and large-scale ( $>50 \mathrm{GWh} / \mathrm{a})$ users of forest chips at right side map. 
first stage. The supply area will be quadrupled with double the The rest was available for other users. Secondly, the outside supply area was calculated with a distance double that used in the distance, and $17 \%$ of this area was allocated to the plant, with the rest being volume free for other users (Figure 2). From the overlapping area, the free volume (i.e., collection sites) was allocated by a method minimising the transport distance between alternative users.

Especially in areas with high forest fuel demand and several overlapping supply areas, the transport distances increased. However, the areas with the highest demand also had the highest potential in central and eastern Finland. The western part of the country was outside the scope of the study. The intensity of the competition was illustrated through the use of colours in the map presentation (see Figure 3). Areas depicted in red had the highest competition, and $50 \%$ of the volume was allocated to CHP plants in the region. By contrast, in areas shown in brown, $17 \%$ was allocated; for those in green, all biomass volume was free and no competition existed. The greatest competition was in central and eastern Finland, where are many large-scale CHP-plants with high demand. The individual points with the highest demand were in Jyväskylä, in central Finland (1000 GWh), and in the city of Lappeenranta (800 GWh), in eastern Finland. The north-eastern part of the country had the least competition from biomass.

Forest biomass availability was illustrated in a map presentation via colour shading, with darker colour indicating better biomass availability (Figure 3). The map showed the biomass free after competition. Therefore, availability was best in the northern part of the country, where there was the least competition.
Both the potential and the availability of small diameter energy wood are increasing in the northern part of Finland. Normally, the potential maps without competition showed the opposite situation, since the potential of spruce logging residues and stumps is concentrated in central and eastern Finland (Ranta, 2005).

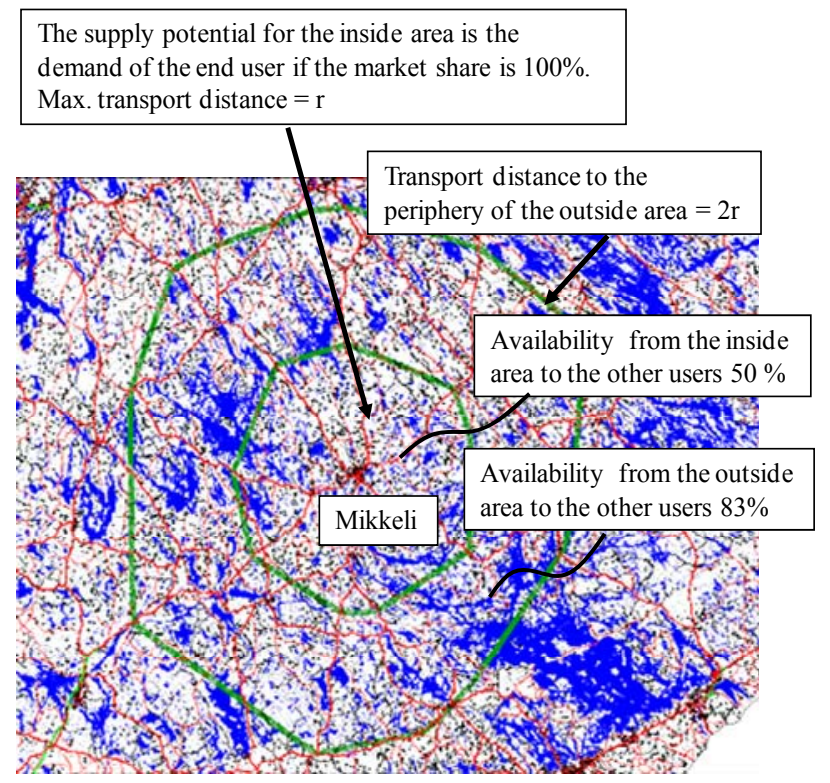

Figure 2.

Isodistance areas and biomass volume allocation rules from the areas.

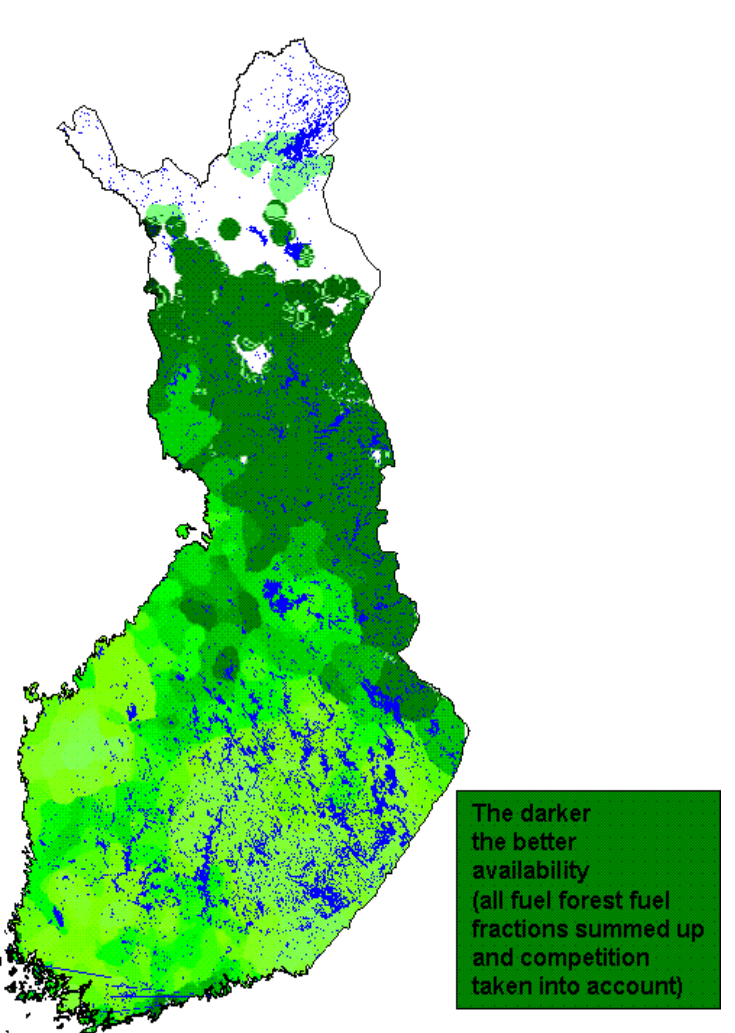

Figure 3.

Competition from biomass. The map at the left illustrates the degree of competition (red for high competiton, orange for minor competiton, green for no competiton) and the one on the right shows the availability after competition has been taken into account (the darger the better availability). All biomass fractions are included. 


\section{Factors in Availability of Biomass to a Biorefinery}

Forest resources, types, and felling activity dictate the biomass potential. So far, the spruce-dominated regeneration fellings have been the main source for forest chips' recovery. Nowadays, also pine-dominated small diameter energy wood fellings and pine stump recovery has become more common. Regional competetion is a very important factor in examination of availability to a specific end-user site. The market share of roundwood fellings and forest-owners' willingness to sell biomass for energy determine the actual free biomass availability. Logging residues and stumps' recovery are typically integrated into roundwood fellings; therefore, access to roundwood fellings provides the possibility of harvesting also energy wood from the same felling site if forest owners are willing to sell it. Forest industry companies are potential biorefinery investors in Finland, and the domestic market share of one company is, on average, one third, although it varies a great deal by region. Forest-owners' willingness to sell was examined in a survey done in the county of Etelä Savo in 2009. Alternative stumpage prices were taken into consideration. The results concerning willingness indicated $80 \%$ for logging residues, $75 \%$ for small-diameter energy wood, and $50 \%$ for stumps. The main reason for declining energy wood harvesting was lack of information and fear of jeopardising the nutrient balance at the forest site.

End-user site location and its proximity to biomass resources, regional geography, and transport networks and related infrastructure are site-dependent factors that dictate availability to the selected end user. The railway and waterway network will widen the procurement area beyond the normal area of less than $100 \mathrm{~km}$ via road network. Overall, the counties of Pohjois-Karjala, Kainuu, and Pohjois-Savo (in the north-east) and the southern part of Lapland are especially suitable for railway or waterway transport logistics.

\section{Supply Logistics Alternatives}

Supply logistics decisions were based on either roadside chipping and direct truck transportation or terminal chipping and railway/waterway transportation to the end-user site. The terminal chipping option included loose material's transportation by trucks to terminals. Only inland and lake-area domestic supply was examined. Import options were excluded from this study.

The terminal sites were existing terminals, and selection for the study was based on suitability to act as a biomass supply terminal for the selected end-user site. Primarily, each location's proximity to biomass sources and transport networks (railway/waterway) dictated the terminal sites. The secondary selection criteria were technical properties and the terminal site's suitability in terms of storage capacity, loading capacity and length of the loading rail or quay, and chipping conditions (remoteness from residential areas). The maximum pre hauling distance for loose material was set to $80 \mathrm{~km}$. Waterway terminals were on Lake Saimaa, along the deep channel (4.2 m). In total, 28 railway terminals and three waterway terminals were chosen (Figure 4).

Railway transportation was based on container logistics. Railway shipment involved 20 wagons each carrying 3 containers (modified $20 \mathrm{ft}, 48 \mathrm{~m}^{3}$ ), for a total frame volume of $2880 \mathrm{~m}^{3}$ of forest chips. The properties of loading places imposed a limit on the train length, less than $450 \mathrm{~m}$, or a 20 -wagon train. The maximum net load would in this case be 976 tonnes, which yields $2380 \mathrm{MWh}$. Each wagon took three containers, with the total,

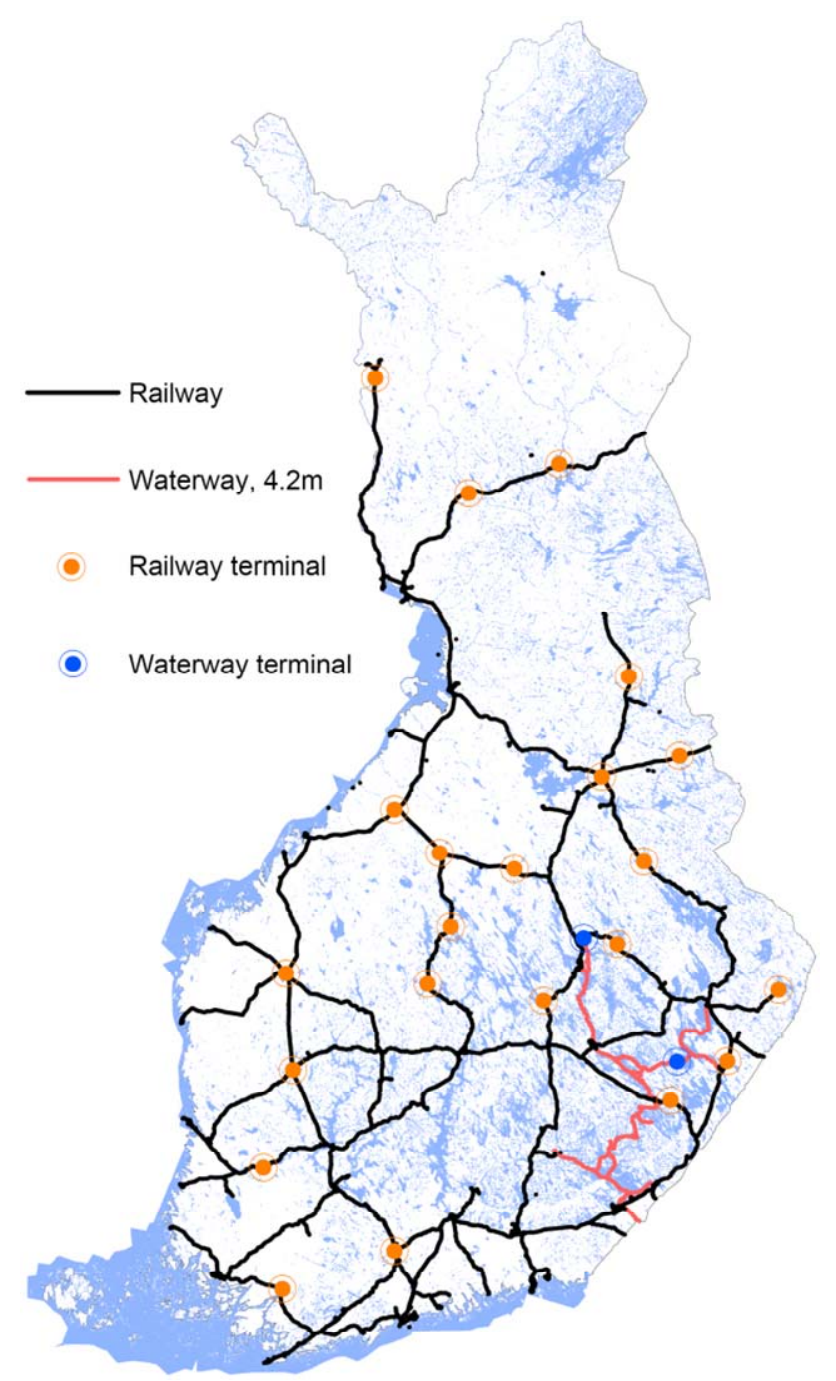

Figure 4.

Railway and waterway terminals.

approx. $140 \mathrm{~m}^{3}$, being equivalent to a full $140 \mathrm{~m}^{3}$ trailer truck. The bearing capacity of one wagon is 61 tonnes, so a fifth of the bearing capacity will remain unused. Loading was done by front loader and unloading with a forklift truck. Forklifts could be equipped with a weighing appliance and RFID-marking system. Biomass was chipped at the railway terminal to keep the degree of capacity utilisation of chipping facilities and trains as high as possible. Biomass was stored for the long term in uncomminuted form, to avoid material loss and any risk of selfignition.

Waterway transportation was based on barge logistics, wherein a tugboat operates with a barge. Only the Lake Saimaa area is suitable for this option, apart from in the winter season, 3 - 4 months for which the lake is frozen. A typical suitable barge size for the Lake Saimaa area is the Europa IIa type: hold: $2650 \mathrm{~m}^{3}$, load with heaped shape: $4000 \mathrm{~m}^{3}$, approx. 1200 tonnes. Storage and chipping were done as with railway logistics. Loading and unloading were done by heavy material machines or excavators. Larger loads are possible with extended sides, since there is still a lot of carrying capacity (maximum: 2500 tonnes) left. Uncomminuted biomass from islands will come as deck load, 
but for this study those options were excluded.

\section{Supply Costs of Alternative Supply Chain Options}

First supply cost without transport was calculated for each biomass fraction. Each collection point had alternative transportation options, either direct truck transportation to the end user or transportation via terminals to the end user (Figure 5). Direct transport involved roadside chipping and truck transport of forest chips. Stump biomass was chipped not at the roadside but at terminals only, or it was transported as uncomminuted loads to the end user. Terminal options included also loose biomass truck transportation to terminals and further forest chip transportation to the end user by either railway or waterway, according to the terminal type.

Logging residues were the cheapest source of raw material, ahead of stumps and small-diameter energy wood. Small-diameter energy wood harvesting and chipping received a production subsidy. Without that, they would not be a competitive source (Figure 6).

Secondly, the transportation cost was calculated for each collection site, for the end user and alternative terminals. The cheapest option was selected, either direct transport or transport via terminal. The increase in truck transportation costs was much greater than the increase for railway or waterway transport $(\mathbf{F i}-$ gure 7). The larger individual loads - by railway 20 trucks and by water 30 - 40 trucks - flatten out the growth in transport costs with these options. The cost functions were based on earlier studies, with updated cost parameters applied (Karttunen et al., 2008; Ranta \& Rinne, 2006; Ryymin et al., 2008).

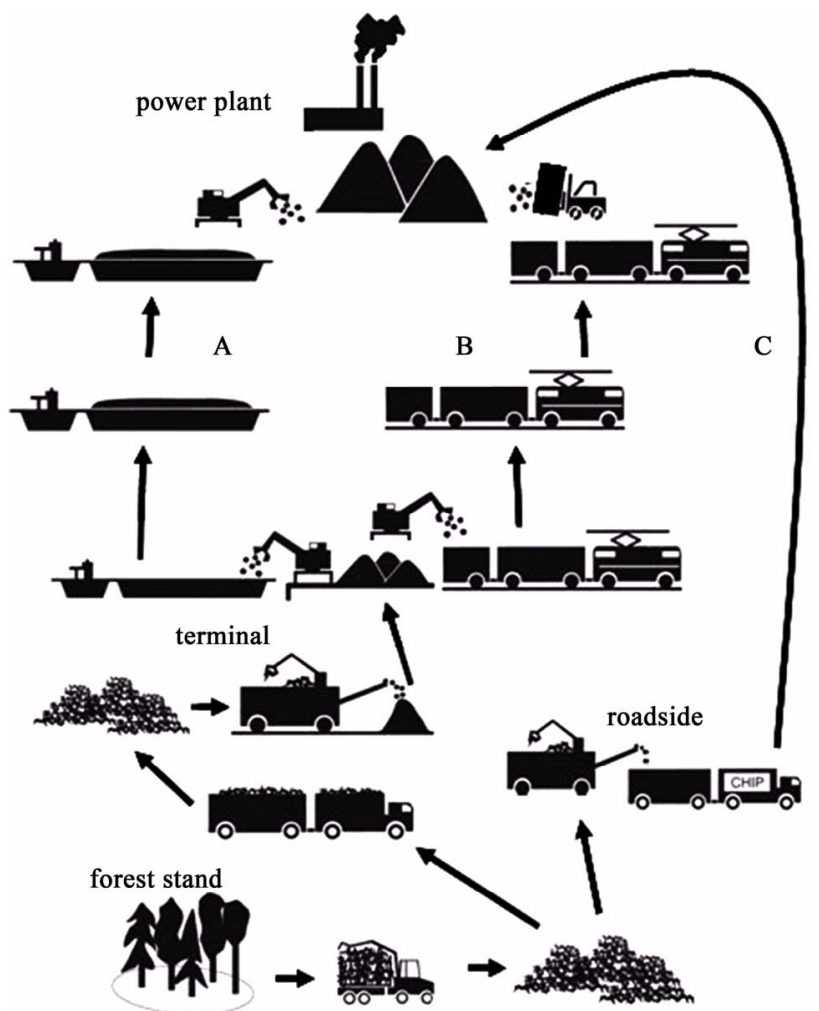

Figure 5.

Alternative supply chain option for forest chips: waterway route A, railway route $\mathrm{B}$, and road transport route $\mathrm{C}$ by truck.

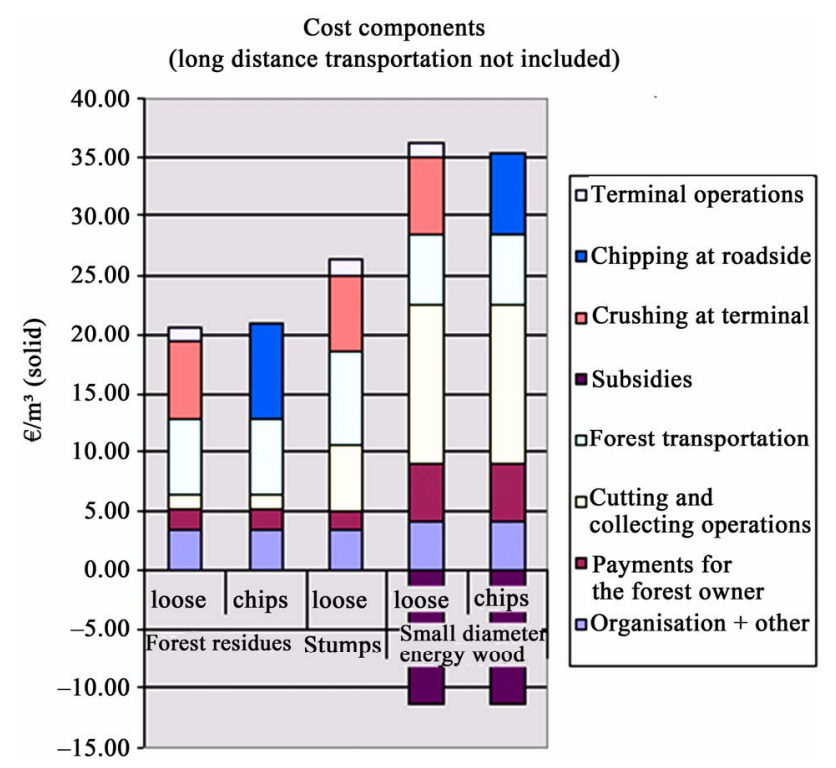

Figure 6.

Supply costs without transportation.

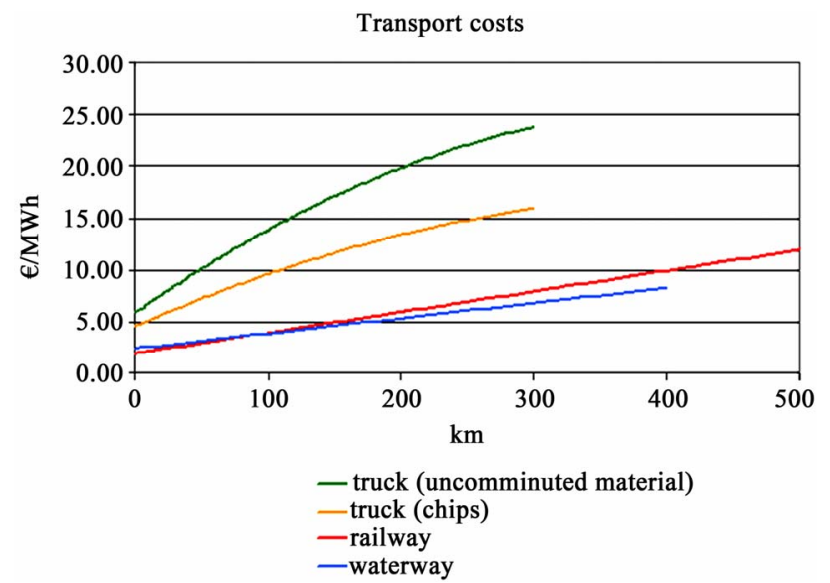

Figure 7.

Transportation cost with alternative long distance transport options (label rank the same as the line rank in the figure).

\section{Estimation of Vehicle and Chipper Capacity Needs}

An important part of the supply logistics planning is estimation of how many vehicles and other machines are needed to feed enough biomass to the biorefinery in view of the supply logistics structure selected. Capacity calculation was based on the annual output of alternative vehicles and machines (Table 1). Capacity values were gathered from earlier studies (Karttunen et al., 2008; Enström, 2008; Ranta \& Rinne, 2006; Ryymin et al., 2008).

\section{Results}

The main results of the study concerned the annual availability of forest biomass in relation to the supply cost and the logistical choices behind this solution for the selected site. The shape of the availability function was a logistics growth curve where the cost increase was faster at the beginning but slowed in the middle to increase again at the end. The procurement area was 
Table 1.

Annual capacity of vehicles and chippers.

\begin{tabular}{lc}
\hline Vehicle/Chipper & $\mathrm{m}^{3} / \mathrm{a}$ \\
\hline Trucks & \\
Logging residues & 21,200 \\
Stumps & 23,600 \\
Energy wood & 21,200 \\
Forest chips & 26,800 \\
Train & 160,000 \\
Barge & 245,000 \\
Mobile chipper & \\
Logging residues at roadside & 46,700 \\
Stumps at terminal & 80,800 \\
Energy wood at terminal & 92,300 \\
\hline
\end{tabular}

limited to below $300 \mathrm{~km}$ when defined as a direct truck transport distance and less than $80 \mathrm{~km}$ when defined as a pre-hauling distance to supply terminals. Therefore, the maximum availability was $4.5 \mathrm{TWh}$ to the selected site. In particular, the market share and forest-owners' willingness to sell limited the total biomass potential to one fourth of the original free techno-economical potential. Local competition, taken into account to determine the free techno-economical potential, decreased availability particularly in eastern Finland.

The average supply costs were used in the figures, while with marginal costs the shape would have been an exponential growth curve. The average supply cost increased steadily at around 2 TWh, which was the targeted supply volume for the plant, corresponding to approx. 1 million $\cdot$ solid $\cdot \mathrm{m}^{3}$. The average supply cost was $17 € / \mathrm{MWh}$ for a $2 \mathrm{TWh}$ supply. One source of supply cost variation was the biomass source. The cheapest was logging residues (16€/MWh), ahead of stumps (17.5€/MWh), and the most expensive was small diameter energy wood ( $21 € / \mathrm{MWh})$, regardless of the production subsidies. Production subsidies decreased the costs of small-diameter energy wood supply by 5.2 $€ / \mathrm{MWh}$ and made these sites one potential energy source. It was assumed that $25 \%$ of energy wood sites were subsidised. Without subsidies, the energy wood fraction would be too expensive. The reason for lower availability of stump biomass was stricter collection site selection rules and less willingness of forest-owners to sell them.

Logging residues accounted for the majority of supply volumes, approx. $70 \%$ of $2 \mathrm{TWh}$ supply, and decreased slowly after this. Stumps accounted for approx. 20\% and subsidised energy wood roughly 10\% (Figure 8). Unsubsidised energy wood became an option until the volume surpassed $2.5 \mathrm{TWh}$ and the supply cost more than $20 € / \mathrm{MWh}$. Truck transport vehicles dominated the transportation, at approx. $70 \%$ for $2 \mathrm{TWh}$ supply, and decreased with larger volumes, to $60 \%$ (Figure 9). The selected site did not have any waterway option.

The map illustrations showed the aerial supply solution, where direct deliveries and delivery via railways terminals take place, and on which raw-material sources these deliveries were based. Direct truck loads were delivered at a transport distance of less than $300 \mathrm{~km}$, and the railway option was possible outside that area, except for small areas surrounding terminals (Figure 10). All biomass sources were transported by truck, but for longer

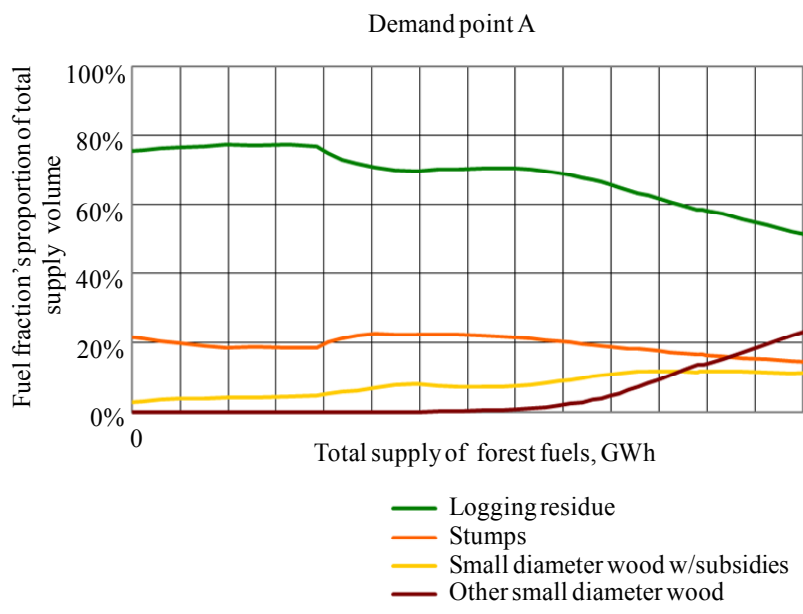

Figure 8.

The shares of alternative biomass sources as a function of total biomass availability (label rank the same as the line rank in the figure).

Demand point A

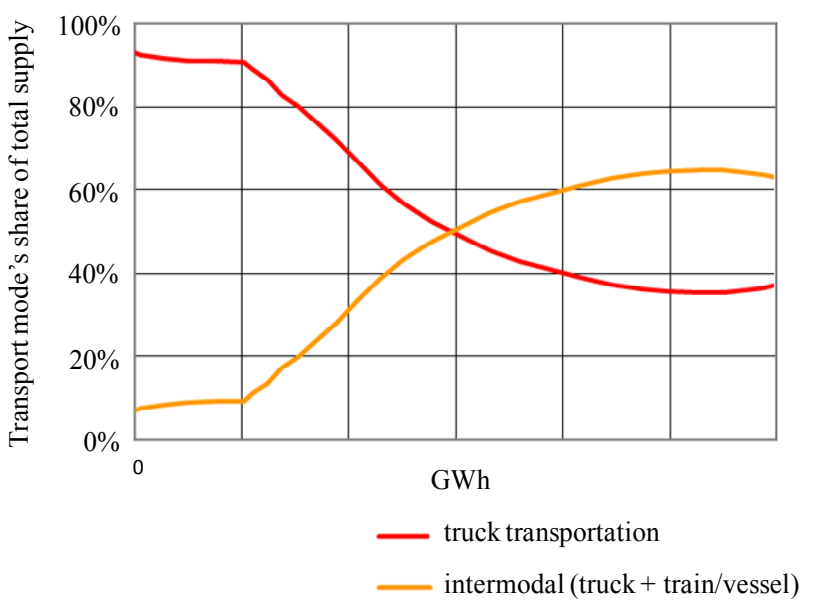

Figure 9.

The share of transport modes as a function of the total biomass availability (label rank the same as the line rank in the figure).

distances only energy wood and finally logging residues were viable option. Stumps were too costly an option for railway transportation.

The vehicle needs for supply of 2 TWh biomass were estimated. In this case, the forest chip trucks and mobile chippers were needed because of the large number of direct deliveries from the roadside. The need for units of other transport modes was marginal (Table 2). To increase the supply from this level will require, in particular, trucks for uncomminuted biomass and mobile chippers for logging residues and energy wood.

\section{Discussion}

The results of biomass availability and supply cost studies are typically very site-dependent, because of the variation in biomass resources, geography, and transport infrastructure. In particular, end-user sites near coastal or border areas have been ranked as poorer sites in comparison to inland sites in this respect (Ranta, 2005). However, long-distance transport with terminal logistics will level off their difference when biomass is also transported 

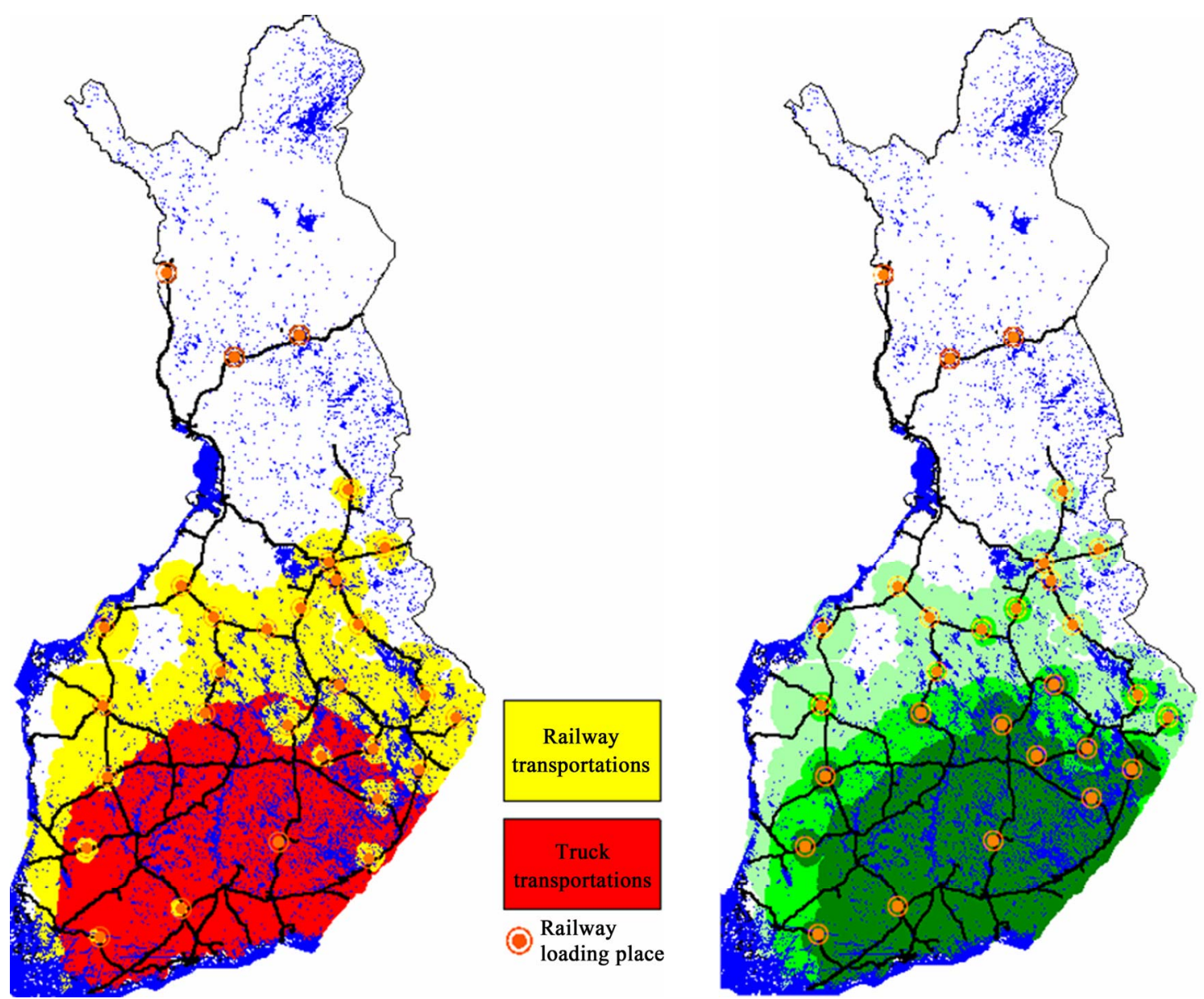

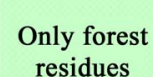

Forest residues

Forest resid
and small diameter energy wood

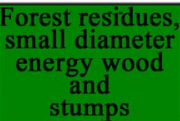

Railway

loading place

Figure 10.

Map illustrating transport mode selection (left side red for trucks and yellow for railway) and biomass raw-material options (right side, dark green for all fractions, middle green without stumps and light green only logging residues ) for 2 TWh supply.

Table 2.

Vehicle needs assuming a supply of 2 TWh.

\begin{tabular}{lc}
\hline Vehicle & Units \\
\hline Truck (uncomminuted biomass) & 9 \\
Truck (forest chips) & 22 \\
Train (20 wagons) & 2 \\
Barge & 0 \\
Mobile chippers (logging residues, energy wood) & 16 \\
Mobile crushers (stumps) & 2 \\
\hline
\end{tabular}

outside the typical procurement area, in which solely truck transportation is used. Coastal sites with their own harbours also have better possibilities for import of a large variety of biomass streams from abroad via large seagoing vessels.

This study shows that the biomass need of a biorefinery is so great that procurement areas must be extended beyond the normal supply area handled with trucks. Typically, truck transport is a suitable option for less than $100 \mathrm{~km}$, because of a rapid increase in transport costs (Ranta \& Rinne, 2006). However, they are still the cheapest transport option for longer distances, with the cost parameters used in this study. The transport costs in- crease to a lesser extent with other transport modes (cf. Figure 7), but the extra stage of pre-hauling to the terminal increases the supply costs with terminals above those of direct transport. However, terminal handling costs form a rather minor cost component, because of efficient material handling machines (cf. Figure 10). If the biorefinery will be somewhere in eastern or central Finland, the variation in biomass availability and supply cost will be minor, because of the need for a large procurement area. The greater the biomass need, the less the variation in biomass availability and supply costs, since almost the whole country will be a potential supply area. Only sites in the north-western and northern part of the country will have a poorer supply situation, especially because of scarcity of logging residues and stumps in that area. Particularly important is a site's location in relation to transport networks, where there should be easy access in all directions, as for a transport node or inland logistics hub.

Mainly terminals outside the $300 \mathrm{~km}$ supply area became part of the supply solution, and supply via closer terminals was less in this study. This phenomenon was taken into account in the selection of terminal sites. The terminal network was rather dense outside the truck supply area (cf. Figure 5). The railway network reaches all over the country well, and the best terminal sites are at branching points of the network or points along the main railway. The loading track length, at minimum $450 \mathrm{~m}$ for 20 wagons, is one important planning parameter - and another 
is the capacity and characteristics of the storage area. Terminals act also as buffer storage; therefore, enough space is needed for both uncomminuted and comminuted biomass, as is stable ground (asphalted concrete), for chipping machines and trucks. Ease of access and short distance between storage and loading track are a self-evident need. For biorefineries, buffer storage capability is particularly essential for maintaining even supply year-round. From forest sites only via direct deliveries, this would not be possible. Therefore, the result of this case study is to some extent theoretical, and more biomass should be directed via terminal supply. The results rely solely on minimising supply costs on the basis of summing costs of supply stages and transport costs. In this case, supply security issues and availability of free vehicle capacity and labour were omitted. In the terminal system, there are better possibilities to increase biomass quality, by controlling the moisture content and impurity levels. There is the possibility of sieving out impurities and selecting and mixing separate biomass lots to homogenise deliveries. Vehicle needs (trucks and mobile chippers) will be lower for a terminal system feeding in the same amount of biomass, in comparison to decentralised supply from forest sites to the biorefinery.

In the study, only railway transport was used via terminals, and in this way 20 truckloads were transported in one shipment. Depending on the terminal's location (remote or in the immediate vicinity), also truck transport from terminals would be an option, but it was not considered in this study. Waterway transport based on barges could take 30 - 40 truckloads at a time. The waterway option is viable only in the Lake Saimaa area, where the best terminal sites are existing harbours for roundwood or other commodities. These sites have the best facilities for handling biomass. The waterway deep water channel (4.35 $\mathrm{m})$ reaches a rather large area in eastern Finland, but the maximum transport distances will be to the line between south and north. For example, the route between harbours of Lappeenranta (southernmost) and Joensuu (northernmost on the east channel route) is $312 \mathrm{~km}$ and Lappeenranta and Siilinjärvi (northernmost on the western channel route) is $339 \mathrm{~km}$. These distances are rather short for making waterways a competitive solution, since in most cases the practical distance will be much shorter in this area. Waterway transport will become part of a supply solution only if the biorefinery has its own harbour and is in the lake area. The Saimaa canal connects the lake to the sea, the Gulf of Finland, and also makes imports from abroad possible. The sea transport would be based on dry cargo vessels instead of the barges used in the lake area.

A common challenge with other transport modes is the under-utilisation of capacity, both bearing capacity and utilisation rate. The latter could be addressed with better management of logistics and the first with vehicle structure development. Both railway wagon and barge capacity could be increased by enlargeing the load frame. It is possible to use higher containers in railway wagons or extended sides in barges. Wagon frames could be increased approx. $20 \%$, but to make multi-mode transportation possible, containers should be dimensioned in view of truck logistics. Also, various compacting systems could be used, such as vacuum feed for containers and pressing the load down by running over it with heavy machines for barge loads.

A common challenge with other transport modes is the under-utilisation of capacity, both bearing capacity and utilisation rate. The latter could be addressed with better management of logistics and the first with vehicle structure development. Both railway wagon and barge capacity could be increased by enlarge- ing the load frame. It is possible to use higher containers in railway wagons or extended sides in barges. Wagon frames could be increased approx. $20 \%$, but to make multi-mode transportation possible, containers should be dimensioned in view of truck logistics. Also, various compacting systems could be used, such as vacuum feed for containers and pressing the load down by running over it with heavy machines for barge loads.

So far, no biorefinery investment has been decided on in Finland. The first site's location will have a major effect on the site decision for other potential sites, because of the tighter competition for biomass in the proximity of the biorefinery. Also, other biomass sources may come into play, such as pulpwood, shortrotation forestry, and agro biomass. At the moment, these are more expensive sources, but if there arises a shortage of biomass, other sources will be mobilised. Peat would be an abundant source of biomass, especially in the northern part of the country, but biofuel produced from it would not have an RES label and Finland will not be able to count it toward the commitment set for RES fuel in the traffic sector.

\section{REFERENCES}

Anttila, P., Korhonen, K. T., \& Asikainen, A. (2009). Forest energy potential of small trees from young stands in Finland. In M. Savolainen (Ed.), Bioenergy 2009. Sustainable bioenergy business. 4th international bioenergy conference from 31st August to 4th September 2009 (pp. 221-226). Jyväskylä: FINBIO Publications.

Enström, J. (2008). Efficient handling of wood fuel within the railway system. In K. Suadicani, \& B. Talbot (Eds.), The Nordic-Baltic conference on Forest operations (pp. 53-55), Copenhagen, 23-25 September 2008. Forest and Landscape Working Papers (30/2008).

Karttunen, K., Jäppinen, E., Väätäinen, K., \& Ranta, T. (2008). Metsäpolttoaineiden vesitiekuljetus proomukalustolla. Waterway transportation of forest fuels by barges. (abstract). Lappeenranta University of Technology. LUT Energy. Final Report. EN B-177.

Korpinen, O.-J., Karttunen, K., Ranta, T., \& Jäppinen, E. (2008). Integration of railroads and waterways with forest fuel logistics in Finland. In K. Suadicani, \& B. Talbot, (Eds.), The Nordic-Baltic Conference on Forest Operations (pp. 65-67). Copenhagen, 35-25 September 2008. Forest and Landscape Working Papers (30/2008).

Laitila, J., Asikainen, A., \& Anttila, P. (2008). Energiapuuvarat. In M. Kuusinen, \& H. Ilvesniemi (Eds.), Energiapuun korjun ympäristövaikutukset, tutkimusraportti. Tapion ja Metlan julkaisuja, Helsinki: Metsäntutkimuslaitos and Metsätalouden kehittämiskeskus Tapio.

Long-term Climate and Energy Strategy. Government Report to Parliament 6 November 2008. Työja elinkeinoministeriön julkaisuja, Energia ja ilmasto (36/2008).

McKeough, P., \& Kurkela, E. (2008). Process evaluations and design studies in the UCG project 2004-2007. Espoo. VTT Tiedotteita, Research notes 2434 .

Metinfo. Forest information services (2009). http://www.metla.fi/metinfo/index-en.htm

Pöyry Energy Oy (2009). Metsäbioenergian saatavuus energiantuotantoon eri markkinatilanteissa. Loppuraportti 30.4.2009. Energiateollisuusry.

Ranta, T. (2005). Logging residues from regeneration fellings for biofuel production-A GIS-based availability analysis in Finland. Biomass and Bioenergy, 28, 171-182. doi:10.1016/j.biombioe.2004.08.010

Ranta, T., \& Rinne, S. (2006). The profitability of transporting uncomminuted raw materials in Finland. Biomass and Bioenergy, 30, 231237. doi:10.1016/j.biombioe.2005.11.012

Ryymin, R., Pohto, P., Laitila, J., Humala, I., Rajahonka, M., Kallio, J. et al. (2008). Metsäenergian hankinnan uudistaminen. Loppuraportti 12/2008.

Statistics: Energy supply, consumption and prices [e-publication]. ISSN=1798-338X. 4th quarter 2010. Helsinki: Statistics Finland [referred: 1.9.2011].

Ylitalo, E. (2011). Puun energiakäyttö 2010. Metsäntutkimuslaitos, Metsätilastotiedote (16/2011). 